Original research article

\title{
Mother-infant bonding and its associated factors during postpartum period
}

\author{
Lucia Mazúchová $^{1 *}$, Simona Kelčíková ${ }^{1}$, Erika Maskalová ${ }^{1}$, Nora Malinovská ${ }^{2}$, Marián Grendár ${ }^{3}$ \\ ${ }^{1}$ Comenius University in Bratislava, Jessenius Faculty of Medicine in Martin, Department of Midwifery, Martin, Slovak Republic \\ ${ }^{2}$ Comenius University in Bratislava; Jessenius Faculty of Medicine in Martin, Department of Foreign Languages, Martin, Slovak Republic \\ ${ }^{3}$ Comenius University in Bratislava, Jessenius Faculty of Medicine in Martin, Bioinformatics Unit, Biomedical Center Martin, Martin, Slovak Republic
}

\begin{abstract}
Aim: The aim of the study was to determine the relationship between the selected factors (age, education, parity, child planning, skin-toskin contact (SSC) support, breastfeeding, partner support satisfaction, a child with an illness, risk of depression) and their influence on postpartum mother-infant bonding (MIB) in Slovak women.

Methods: A cross-sectional study was used. To collect the relevant data, the Postpartum Bonding Questionnaire (PBQ) and Edinburgh Postnatal Depression Scale (EPDS) were used. The questionnaires were supplemented by research variables essential for the evaluation of the links between these items and the MIB. The study sample consisted of 204 women (mean age $30.9 \pm 4.8$ years) who were 6 weeks after childbirth. The received data were analysed using descriptive statistics, the Wilcoxon two-sample test, the Kruskal-Wallis test, and the Regression modelling.

Results: A lower quality mother-infant relationship was demonstrated in mothers with higher education, with unsupported postpartum SSC, dissatisfied with partner support, as well as in mothers at risk of depression. According to the regression model, a statistically significant correlation was demonstrated between the PBQ score and the EPDS score $(p<0.0001)$.

Conclusions: Identification of MIB risk factors with an emphasis on screening for the mother's mental state is considered to be a key factor in designing early interventions to improve the quality of pregnancy, motherhood and childhood.
\end{abstract}

Keywords: Mother-infant bonding; Postnatal depression; Postpartum bonding; Postpartum period; Quality of mother-infant interaction

\section{Introduction}

Secure attachment is a basic human need necessary for the formation of a close and confidential relationship between infants and their caregivers (Hong and Park, 2012). Attachment acts like an invisible connection that helps maintain a close relation between the mother and the child and is considered an important part of a child's development (Salehi and Kohan, 2017). Bowlby (1969), who introduced the attachment theory, defined attachment as "a set of internal behaviours that would cause the infant to become closely related to his/her main caregiver, who is usually the mother". According to Bowlby's attachment theory, a congenital repertoire of attachment behaviour (i.e. attachment behavioural manifestations) can be observed in children. This theory reflects the importance of early close mother-infant bonding (MIB) and psychosocial factors for mental health and personality organization, functional interactions and essential neurobiological processes, including emotional, cognitive, social and other interactions (Bowlby, 1980).
MIB starts developing during pregnancy and this development continues after birth (Petri et al., 2018). MIB predicts the quality of the mother-infant interaction after birth, which has been shown to be important for the child's development (Fuchs et al., 2016). The quality of the mother-child relationship naturally affects the level of trust, love, protection and prolonged breastfeeding (De Falco et al., 2014). Early attachment relationships play an important role in a child's psychological, cognitive and social development. There is substantial evidence that children with secure attachments in childhood develop more positive social-emotional competence, cognitive functioning, physical health and mental health, whereas children with insecure attachments are more at risk for negative outcomes in these domains. Although most mothers do not have difficulty in forming a loving relationship with their baby, postpartum disorders are present in $10-11 \%$ of women in the entire population (Falceto et al., 2012). MIB disorder is reported as a delay in the emotional response towards a child, accompanied by feelings of irritation, hostility, aggressive impulses, or rejection. These relationship disorders can increase the risks of maltreatment as well as psychopathology in children (Lehnig et al., 2019).

\footnotetext{
* Corresponding author: Lucia Mazúchová, Comenius University in Bratislava, Jessenius Faculty of Medicine in Martin, Department of Midwifery, Malá Hora 5, 03601 Martin, Slovak Republic; e-mail: mazuchova@jfmed.uniba.sk http://doi.org/10.32725/kont.2021.018

Submitted: 2021-01-04 • Accepted: 2021-04-08 • Prepublished online: 2021-04-15 
Previous studies have shown that the attachment between mother and child is influenced by a number of factors, such as family history, socioeconomic, cultural factors, support systems, breastfeeding (Linde et al., 2020), postpartum skin-toskin contact (SSC) support (Mazúchová et al., 2020; Moore et al., 2012), pregnancy planning (Ekrami et al., 2020) maternal psychiatric disorder (McNamara et al., 2019), particularly depressive symptoms (Nieto et al., 2017), and finally parental stress related to caring for a child with an illness (Bernard et al., 2019).

The trans-generational transfer also plays a vital role in the development of attachment. There is a direct correlation between the parents' relationship, their behaviour towards the child and the child's bonding (Brisch, 2011). Parents who experienced a safe bond in their own childhood are more likely to create the same bond with their child. Conversely, parents with a tenuous attachment (who themselves had faced rejection or whose parents had been ambivalent towards their needs) will be hard pushed to respond adequately to the needs of their child.

Given the important effects of postpartum MIB on the future health and development of the child and the mother, we found it essential to examine the factors that impair the quality of the MIB in order to identify and support (as early as possible) the mothers who are at an increased risk of bonding problems.

The aim of the study was to determine the relationship between the selected factors (age, education, parity, child planning, SSC, breastfeeding, partner support satisfaction, a child with an illness, risk of depression) and their influence on postpartum MIB in Slovak women.

\section{Materials and methods}

\section{Design}

A cross-sectional study was used.

\section{Setting}

A convenience sampling method was used. The women gave birth in two university hospital birth centres: Martin and Bratislava. One hospital was located in the capital city (Bratislava) and one hospital in the central part of Slovakia (Martin). The sample group consisted of women who had fulfilled the following inclusion criteria: women within 6 weeks after delivery, having given birth to a live baby, willing to cooperate, and having signed the written consent.

\section{Sample}

The sample group consisted of 204 postpartum women (mean age $30.9 \pm 4.8$ years), who were 6 weeks after delivery. As many as $62.2 \%$ of the women were from Martin University Hospital and $37.8 \%$ from Bratislava University Hospital. The characteristics of the sample with respect to the variable criteria (age, educational attainment, parity, planning for pregnancy, SSC, breastfeeding, partner support satisfaction, a child with an illness, risk of depression) are presented in Table 1.

\section{Procedure}

Data collection was conducted from September 2018 to April 2020. The research participants who agreed to take part in the research project voluntarily provided e-mail addresses and were instructed in how to complete the questionnaire (which was subsequently sent to them 6 weeks after delivery). Out of 584 questionnaires sent electronically to e-mail addresses,
204 completed questionnaires were returned, representing a response rate of $34.9 \%$.

\section{Measures}

In order to collect the relevant data, the following measuring instruments were used: Postpartum Bonding Questionnaire (PBQ) and Edinburgh Postnatal Depression Scale (EPDS). The questionnaires were supplemented by research variables (age, education, parity, child planning, SSC, breastfeeding, partner support satisfaction, a child with an illness, risk of depression) essential for the research set characteristics as well as for the evaluation of the links between these items and MIB.

The standardized questionnaire PBQ (Brockington et al., 2006), serving as a screening tool for detection of bonding quality between mother and child as well as detection of problems in early diagnosis of bonding disorders, was used to collect the data. It consisted of 25 questions evaluated using the 6 -point Likert scale. The lowest possible score was 0 and the maximum score was 125 . The higher the average scale value of responses, the worse (less safe/lower quality) the mother-infant relationship evaluation. The PBQ was translated into Slovak through the method of back-translation. The internal consistency reliability (the Cronbach alpha reliability) coefficient of the PBQ in this research was 0.92. Permission to use PBQ was obtained from the author of the questionnaire.

Symptoms of maternal depression were assessed by the EPDS (Cox et al., 1987). It is a 10-item self-rating scale, scored from 0 to 3, with which women rated how they had felt over the last 7 days. The lowest possible score was 0 and the maxi-

\section{Table 1. Descriptive characteristics of the respondents}

\begin{tabular}{lc}
\hline Characteristic $(n=204)$ & $n(\%)$ \\
\hline Age & \\
18 to 20 years old & $2(0.98)$ \\
21 to 30 years old & $83(40,69)$ \\
31 to 40 years old & $110(53.92)$ \\
41 to 50 years old & $9(4.41)$ \\
\hline Education & \\
Lower education & $64(31.37)$ \\
Higher education & $140(68.63)$ \\
\hline Parity & \\
$\quad$ Primiparous & $116(57.43)$ \\
Multiparous & $86(42.57)$ \\
Missing data & 2 \\
\hline Child planning & \\
Yes & $152(74.51)$ \\
No & $52(25.49)$ \\
\hline Support of SSC & \\
Yes & $97(47.55)$ \\
No & $107(52.45)$ \\
Breastfeeding & \\
Yes & $136(66.66)$ \\
No & $68(33.33)$ \\
\hline Partner support satisfaction & \\
Yes & $181(88.73)$ \\
No & $23(11.24)$ \\
\hline A child with an illness & \\
Yes & $9(4.41)$ \\
No & $195(95.59)$ \\
Risk of depression & \\
Yes & $45(22.72)$ \\
Missing data & $153(77.27)$ \\
\hline & 6 \\
\hline
\end{tabular}


mum score was 30. Different cut-off points were used. According to the EPDS Manual - 2nd edition (2014), a recommended cut-off score of 10 points or more is suitable for research, indicating elevated levels of depressive symptoms. Respondents who had $\geq 10$ points were labelled as being at risk of depression and those who had $<10$ points were labelled as being without risk of depression. The EPDS was translated into Slovak through the method of back-translation. The internal consistency reliability (the Cronbach alpha reliability) coefficient of the EPDS in this research was 0.88. Permission to use EPDS was obtained from the Royal College of Psychiatrists (UK).

\section{Ethical considerations}

The study was approved by the Ethics Committee of the Jessenius Faculty of Medicine in Martin, Slovakia (Number EK $36 / 2018$ ). All participants received full information about the nature and goals of the research, as well as about the details connected with their involvement in the study. The data collection was anonymous, and all participants expressed their willingness to be included in the study, attaching their informed consent.

\section{Data analysis}

Data were explored and analysed using R (R Core Team, 2018) ver. 3.5.2, with the aid of the gt_summary (Sjoberg et al., 2020) and beeswarm (Eklund, 2016) libraries. Data on a continuous variable at different levels of a categorical variable (PBQ vs education, parity, child planning, SSC, breastfeeding, partner support satisfaction, a child with an illness, risk of depression) were visualized by a swarmplot overlaid with a boxplot and analysed either by the Wilcoxon two-sample test (in the case of a factor with two levels) or by the Kruskal-Wallis test (if there were more than two levels of a factor). Association between two continuous variables (Age and PBQ, PBQ and EPDS) was exhibited by the crossplot and analysed by means of regression modelling with an appropriate form of the functional dependence. Effect size in the regression was quantified by the Adjusted $\mathrm{R}^{2}$.

\section{Results}

Table 1 presents the basic characteristics of participants.

The mean age of the participants was $30.9 \pm 4.8$ years, ranging from 20 to 44 years of age.

The most represented female age groups were women aged 31 to $40(53.92 \%)$ and women aged 21 to 30 (40.69\%). The majority of women (68.63\%) had attained higher education and $31.37 \%$ had completed lower education (with secondary school education and with primary education). In terms of parity, the research group consisted of $57.43 \%$ of primiparas and $42.27 \%$ of multiparas. Most women had $(74.51 \%)$ planned their child. Considering SSC, $47.55 \%$ of the women reported that they had been given SSC support according to the recommended procedures (i.e. immediate and uninterrupted SSC, possibly with a short interruption due to a newborn physical examination, lasting at least $3 / 4$ hours) while $52.45 \%$ of the women had not received it. As many as $66.66 \%$ of the women breastfed. Satisfaction with partner support was reported by $88.73 \%$ of the women. In terms of child health-related problems, $4.41 \%$ of the women had a child with an illness. Using the EPDS scale, risk of depression was reported in $22.72 \%$ of the women. Table 2 presents individual item characteristics of the PBQ.

Table 2. Individual item characteristics of the PBQ

\begin{tabular}{|c|c|c|c|c|c|}
\hline Questions in PBQ & Mean (SD) & Min & Max & Median & Modus \\
\hline 1. I feel close to my baby & $0.36(0.67)$ & 0.00 & 3.00 & 0 & 0.00 \\
\hline 2. I wish the old days when I had no baby would return & $0.75(0.96)$ & 0.00 & 5.00 & 0 & 0.00 \\
\hline 3. I feel distant from my baby & $0.33(0.69)$ & 0.00 & 4.00 & 0 & 0.00 \\
\hline 4. I love to cuddle my baby & $0.47(0.84)$ & 0.00 & 5.00 & 0 & 0.00 \\
\hline 5. I regret having this baby & $0.09(0.47)$ & 0.00 & 5.00 & 0 & 0.00 \\
\hline 6. This baby doesn't seem to be mine & $0.10(0.47)$ & 0.00 & 4.00 & 0 & 0.00 \\
\hline 7. My baby winds me up & $0.77(0.58)$ & 0.00 & 4.00 & 1 & 0.00 \\
\hline 8. I love my baby to bits & $0.15(0.52)$ & 0.00 & 5.00 & 0 & 0.00 \\
\hline 9. I feel happy when my baby smiles or laughs & $0.02(0.16)$ & 0.00 & 1.00 & 0 & 0.00 \\
\hline 10. My baby irritates me & $0.79(0.81)$ & 0.00 & 4.00 & 1 & 1.00 \\
\hline 11. I enjoy playng with my baby & $0.46(0.72)$ & 0.00 & 4.00 & 0 & 0.00 \\
\hline 12. My baby cries too much & $1.46(1.02)$ & 0.00 & 5.00 & 1 & 1.00 \\
\hline 13. I feel trapped as a mother & $0.77(1.04)$ & 0.00 & 5.00 & 0 & 0.00 \\
\hline 14. I feel angry with my baby & $0.26(0.59)$ & 0.00 & 4.00 & 0 & 0.00 \\
\hline 15. I resent my baby & $0.02(0.16)$ & 0.00 & 1.00 & 0 & 0.00 \\
\hline 16. My baby is the most beautiful baby in the world & $0.08(0.33)$ & 0.00 & 2.00 & 0 & 0.00 \\
\hline 17. I wish my baby would somehow go away & $0.06(0.36)$ & 0.00 & 3.00 & 0 & 0.00 \\
\hline 18. I have done harmful things to my baby & $0.05(0.23)$ & 0.00 & 1.00 & 0 & 0.00 \\
\hline 19. My baby makes me feel anxious & $0.29(0.67)$ & 0.00 & 4.00 & 0 & 0.00 \\
\hline 20. I am afraid of my baby & $0.07(0.40)$ & 0.00 & 4.00 & 0 & 0.00 \\
\hline 21. My baby annoys me & $0.23(0.50)$ & 0.00 & 2.00 & 0 & 0.00 \\
\hline 22. I feel confident when caring for my baby & $1.02(0.96)$ & 0.00 & 5.00 & 1 & 1.00 \\
\hline 23. I feel the only solution is for someone else to look after my baby & $0.15(0.46)$ & 0.00 & 3.00 & 0 & 0.00 \\
\hline 24. I feel like hurting my baby & $0.09(0.34)$ & 0.00 & 2.00 & 0 & 0.00 \\
\hline 25. My baby is easily comforted & $1.52(1.10)$ & 0.00 & 5.00 & 1 & 1.00 \\
\hline
\end{tabular}


The analysis of the PBQ showed that the highest average score was in the questionnaire entries: "My baby is easily comforted" (1.52 \pm 1.10$)$, "My baby cries too much" $(1.46 \pm 1.02)$ and "I feel confident when caring for my baby" (1.02 \pm 0.96$)$.
Table 3 presents the relationship between the examined factors (age, education, parity, child planning, support SSC, breastfeeding, and partner support satisfaction) and PBQ.

\section{Table 3. Examined factors of PBQ}

\begin{tabular}{|c|c|c|c|}
\hline Characteristic $(n=204)$ & Mean (SD) & Median & $p$ value $^{*}$ \\
\hline \multicolumn{4}{|l|}{ Age } \\
\hline 18 to 20 years old & $15.50(13.44)$ & $16(11.20)$ & \\
\hline 21 to 30 years old & $11.14(10.55)$ & $9(5.15)$ & \\
\hline 31 to 40 years old & $10.12(9.43)$ & $8(4.14)$ & \\
\hline 41 to 50 years old & $5.78(4.09)$ & $5(3.8)$ & $0.2^{\mathrm{a}}$ \\
\hline \multicolumn{4}{|l|}{ Education } \\
\hline Lower education & $8.56(11.76)$ & $5(2.10)$ & \\
\hline Higher education & $11.24(8.66)$ & $9(5.15)$ & $<0.001^{\mathrm{b}}$ \\
\hline \multicolumn{4}{|l|}{ Parity } \\
\hline Primiparous & $10.82(10.58)$ & $8(4.14)$ & \\
\hline Multiparous & $10.05(8.65)$ & $8(4.14)$ & $0.586^{\mathrm{b}}$ \\
\hline \multicolumn{4}{|l|}{ Child planning } \\
\hline Yes & $9.70(8.75)$ & $8(4.13)$ & \\
\hline No & $12.42(12.21)$ & $9(4.18)$ & $0.194^{\mathrm{b}}$ \\
\hline \multicolumn{4}{|l|}{ Support of SSC } \\
\hline Yes & $8.45(7.08)$ & $7(3.12)$ & \\
\hline No & $12.16(11.47)$ & $10(5.15)$ & $0.023^{b}$ \\
\hline \multicolumn{4}{|l|}{ Breastfeeding } \\
\hline Yes & $10.45(9.88)$ & $8(4.14)$ & \\
\hline No & $10.29(9.66)$ & $8(4.14)$ & $0.9^{\mathrm{b}}$ \\
\hline \multicolumn{4}{|l|}{ Partner support satisfaction } \\
\hline Yes & $9.86(9.64)$ & $8(4.13)$ & \\
\hline No & $14.65(10.14)$ & $14(6.18)$ & $0.027^{b}$ \\
\hline \multicolumn{4}{|l|}{ A child with an illness } \\
\hline Yes & $14.67(16.55)$ & $9(7.10)$ & \\
\hline No & $10.20(9.38)$ & $8(4.14)$ & $0.7^{\mathrm{b}}$ \\
\hline \multicolumn{4}{|l|}{ Risk of depression } \\
\hline Yes & $19.44(14.62)$ & $16(9.26)$ & \\
\hline No & $7.57(5.57)$ & $6(3.11)$ & $<0.001^{\mathrm{b}}$ \\
\hline
\end{tabular}

The following factors were not found to be statistically significant for postpartum relationship: age $(p=0.2)$, parity $(p=0.586)$, child planning $(p=0.194)$, breastfeeding $(p=0.9)$ and childhood disease $(p=0.7)$.

Statistically significant differences in postpartum MIB were demonstrated in terms of education $(p<0.001)$, SSC support $(p=0.023)$, partner support satisfaction $(p=0.027)$ and risk of depression $(p<0.001)$. The mean score showed that the lower quality MIB was demonstrated in the mothers: with higher education (11.24 \pm 8.66$)$; with unsupported postpartum SSC (12.16 \pm 11.47$)$; dissatisfied with partner support (14.65 \pm 10.14$)$; and at risk of depression (19.44 \pm 14.62$)$.

According to the regression model, plotting the cubic polynomial model with R-squared $=0.451$, a statistically significant correlation $(p<0.0001)$ was demonstrated between the PBQ score and the EPDS score.

\section{Discussion}

In accordance with the results of our study, the highest score of the PBQ was shown in the items "My baby is easily comforted" and "My baby cries too much" (Table 2). Perceived exces- sive infant crying has potentially dangerous consequences to the health and well-being of parents, infants and their mutual interaction (Mohebati et al., 2014). Excessive or uncontrollable crying of a child can cause stress to parents, contribute to insensitive or aggressive reactions, disrupt parenting, and in some cases expose the child to the risk of maltreatment (Zeifman and St James-Roberts, 2017). Kommers et al. (2017) have shown a link between the infant cry rate and the prenatal quality of MIB. He suggests that mothers with lower attachment scores reported having children that cry excessively. Support programs that inform parents about child crying, enhance parenting, and improve parental well-being and coping (Zeifman and St James-Roberts, 2017). The PBQ item "I feel confident when caring for my baby" also showed a higher score. Maternal self-confidence has been considered a fundamental variable for compatibility with maternal role. The women who receive education and information about pregnancy, childbirth, and parental roles, along with conscious expectations at each stage of pregnancy and motherhood, show a higher degree of confidence and competence in fulfilling their maternal role (Fasanghari et al., 2019). Maternal role training is an effective intervention in increasing self-confidence in childcare and promoting maternal identity (Hyun-Ju and Sue, 2011). 
The major findings of our study are the proven factors related to postpartum attachment, namely education, SSC, partner support satisfaction and the risk of depression (Table 3 ).

There were significant differences confirmed between women with lower and higher education; the women with lower education proved to have better attachment with their child than the women with higher education. We can assume that the Slovak women with lower education might be more emotional, and the women with higher education more rational and critical. Similar results have been also reported in other studies (Kinsey et al., 2014; Lehnig et al., 2019). Kinsey et al. (2014) have suggested that the link between higher maternal education and MIB disorder may be distorted by the fact that more educated women may be more likely to respond honestly about their relationship with the child and, conversely, less educated women may tend to respond in a socially desirable way. Other studies have not shown significant differences in terms of education (Daglar and Nur, 2018; Örün et al., 2013). However, another study (Dubber et al., 2015) has arrived that shows opposite results, attributing higher levels of prenatal attachment in mothers to higher education.

The period shortly after childbirth is considered an important period for the attachment formation, and the early SSC is also recognized as an important factor in this context (Hrubý, 2017). According to our results, the SSC support has proven to be another significant factor influencing the quality of postpartum MIB. Other studies have confirmed the association between SSC and bond quality (Mazúchová et al., 2020; Phillips, 2013). SSC immediately after birth initiates the early onset of maternal behaviour towards the baby. The mother can easily decipher the needs of the child and can respond to them adequately, thus providing a precondition for a secure attachment between the mother and the child. On the other hand, those women who were separated from their children after birth often have child-related disorders (excessively protective or denial behaviour, feelings of mistrust in their own parental abilities) (Bryanton et al., 2008). Given the existing scientific evidence of the importance of SSC - emphasizing its irreplaceable benefits for both children and mothers (Moore et al., 2012) - it is highly unsatisfactory that more than half of the women in our study were not given SSC support. According to a systematic review, higher levels of SSC support are reported in some countries such as Croatia (98\%), Denmark (96\%), Switzerland (95\%), Finland (89\%), Canada (81\%) or Italy $(80 \%)$. By contrast, lower levels of SSC support have been found in Brazil (34\%), Mexico (10\%) or Ethiopia (8\%). Given the existing scientific evidence of the importance of SSC that emphasizes its irreplaceable benefits for both children and mothers (Moore et al., 2012), this is highly unsatisfactory (Abdulghani et al., 2018). It is essential for midwives to support uninterrupted SSC immediately after birth, thus supporting the initiation and development of secure attachment.

Satisfaction with partner support has shown to be another significant factor related to postpartum MIB. Similarly, a study by Matthies et al. (2020) has revealed that women with high partner satisfaction have better binding abilities, which may indicate safer binding behaviour. The quality of parenting correlates with the quality of the partners' relationship (Falceto et al., 2012). The area of female satisfaction with partner support cannot be directly influenced. However, it is essential to inform the partners about the possibility to support their women already during the period of pregnancy, childbirth, as well as after the birth of a child. It is also important to involve the partners in participation in successful building and sustaining the relationship with the child, and helping with the childcare, which all significantly contribute to the woman's well-being and mental health. Preventive programs during pregnancy should strengthen strategies to support MIB as well as to improve partnerships and increase the social level of support.

Postpartum depression is one of the serious diseases that affect the health of the women and the child - but also functioning of the entire family (Hendrych Lorenzová et al., 2016). Mental health not only affects maternal well-being, but can also have a significant effect on the mother's ability to form a healthy bond with her child (Pereira et al., 2012). A systematic review by McNamara et al. (2019) states that the prevalence of depression in the prenatal and postnatal period ranges from $9 \%$ to $59 \%$. Severe and persistent symptoms of maternal depression are associated with adverse outcomes in children's mental health (Netsi et al., 2018). In our study, $22.72 \%$ of women were at risk for depression. Our findings support the claim that maternal mental state may negatively influence the ongoing process of MIB in the early postpartum period. The risk of depression has been shown to be another significant factor associated with postpartum MIB. Several studies have presented an association between the symptoms of postpartum depression and maternal attachment (Delavari et al., 2018; Dubber et al., 2015; Kinsey et al., 2014; Lehnig et al., 2019; Lutkiewicz et al., 2020). According to the regression model, there was a significant correlation between the PBQ score and the EPDS score. Huizink et al. (2017) have stated that maternal depression is associated with a lack of confidence in childcare - as a result of which mothers may perceive themselves as less.

Understanding MIB behaviour could play an important role in the quality of prenatal care. Early identification of bond impairment during pregnancy and postpartum depression in mothers contributes significantly to preventing possible deterioration in MIB in the early postpartum period. Midwives can assess and promote attachment behaviour as well as recognize factors influencing MIB (Jamshidimanesh et al., 2013), which is important in terms of preventing the processes that are currently considered crucial to the emergence of lifelong psychopathology (Nóblega et al., 2019).

We consider it highly important to emphasize the significance of preparing future parents for the arrival of the child so that they can adequately handle stressful situations, either during or after pregnancy. The ideal solution would be parenting support programs focused on preparation for parenthood and bond support, which would inform parents in detail about all possible issues and changes related to their transition to parenthood (e.g. infant crying) and which would help to enhance parenting and improve parental well-being.

\section{Limitations of the study}

Certain limitations were inherent to the nature of the research (i.e. online questionnaires, convenience sample, and the number of respondents). The factors that are linked to bonding quality are also considered limiting. We realize that many other factors, such as social environment, family financial status, family mental health history, as well as the support and assistance of family members in childcare also influence mother-infant bonding quality. As a result, based on our research, it cannot be argued that only the examined variables are related to bonding quality. The study may be considered as partial. Despite the above limitations, we believe that the study has yielded inspiring results. 


\section{Conclusions}

A lower quality MIB has been demonstrated in the mothers with higher education, with unsupported postpartum SSC, those dissatisfied with partner support, and in mothers at risk of depression. We consider the knowledge and identification of MBI risk factors, with particular emphasis on maternal mental state screening, to be crucial in designing early interventions to support the creation of a strong and healthy bond between a mother and her child, as well as to support the healthy and secure development of children. Midwives and nurses are in a unique position to assess attachment and to promote attachment behaviours. Improving practice at medium-level (development and management of social support), as well as at micro-level (work with pregnant women and parents before childbirth) is highly essential.

\section{Funding}

There was no funding obtained for the study.

\section{Conflict of interests}

The authors declare that they have no conflict of interests.

\section{Author contributions}

Concept and study design (LM, SK, EM), data analysis and interpretation (LM, MG, EM), processing the draft of the manuscript (LM, SK, NM), critical revision of the manuscript (LM, SK, NM), article finalization (LM, NM).

\section{Acknowledgements}

This study was supported by the project VEGA (research grant agency of the Ministry of Education, Science, Research and Sport of the Slovak Republic) under contract no. VEGA1/0211/19.

\section{Popôrodná vzt'ahová väzba medzi matkou a dietatiom a s ňou súvisiace faktory}

\section{Súhrn}

Ciel': Ciel'om štúdie bolo zistit' súvislosti vybraných faktorov (veku, vzdelania, parity, plánovania diet'at'a, podpory kontaktu koža na kožu /skin to skin contact; SSC/, dojčenia, spokojnosti s partnerskou podporou, ochorenia dietatata, rizika depresie) s popôrodnou vztahovou väzbou (mother-infant bonding; MIB) u slovenských žien.

Metódy: Bol zvolený dizajn prierezovej štúdie. Na zber relevantných údajov sa použili dotazník popôrodnej vztahovej väzby (Postpartum Bonding Questionnaire; PBQ) a škála popôrodnej depresie (Edinburgh Postnatal Depression Scale, EPDS). Dotazníky boli doplnené o výskumné premenné nevyhnutné na skúmanie vzt́ahov medzi týmito položkami a MIB. Výskumný súbor tvorilo 204 žien (priemerný vek 30,9 \pm 4,8 rokov), ktoré boli 6 týždňov po pôrode. Na analýzu údajov bola použitá deskriptívna štatistika, Wilcoxon dvojvýberový test, Kruskal-Wallis test a regresný model.

Výsledky: Menej kvalitná väzba medzi matkou a dietatom bola preukázaná u matiek s vyšším vzdelaním, s nepodporeným SSC po pôrode, nespokojných s partnerskou podporou a u matiek s rizikom depresie. Podla regresného modelu medzi PBQ skóre a EPDS skóre sa preukázala štatisticky signifikantná súvislost' ( $\mathrm{p}<0.0001)$.

Záver: Poznanie a identifikovanie rizikových faktorov MIB s dôrazom na skríning psychického stavu matiek považujeme zo strany pôrodných asistentiek za kl'účové pri navrhovaní včasných intervencií pre zlepšenie kvality tehotenstva, materstva a detstva.

Kl'účové slová: bonding po pôrode; kvalita väzby medzi matkou a diet́at'om; popôrodná depresia; popôrodné obdobie; vzt́ahová väzba medzi matkou a dietatom

\section{References}

1. Abdulghani N, Edvardsson K, Amir LH (2018). Worldwide prevalence of mother-infant skin-to-skin contact after vaginal birth: A systematic review. PLoS One 13(10): e0205696. DOI: 10.1371/journal.pone.0205696.

2. Bernard K, Hostinar CE, Dozier M (2019). Longitudinal associations between attachment quality in infancy, C-reactive protein in early childhood, and BMI in middle childhood: preliminary evidence from a CPS-referred sample. Attach Hum Dev 21(1): 5-22. DOI: 10.1080/14616734.2018.1541513.

3. Bowlby J (1969). Attachment and loss: Vol. I. New York: Basic Books, $428 \mathrm{p}$.

4. Bowlby J (1980). Attachment and loss: Vol III. Loss sadness and depression. New York, NY: Basic Books, 355 p.

5. Brisch KH (2011). Bezpečná vzt'ahová väzba. Trenčín: Vydavatel'stvo F, 150 p.

6. Brockington IF, Fraser C, Wilson D (2006). The Postpartum Bonding Questionnaire: a validation. Arch Womens Ment Health 9(5): 233-242. DOI: 10.1007/s00737-006-0132-1.

7. Bryanton J, Gagnon AJ, Hatem M, Johnston C (2008). Predictors of early parenting self-efficacy: results of a prospective cohort study. Nursing Research 57(4): 252-259. DOI: 10.1097/01.NNR.0000313490.56788.cd.
8. Cox JL, Holden JM, Sagovsky R (1987). Detection of postnatal depression. Development of the 10-item Edinburgh Postnatal Depression Scale. Br J Psychiatry 150(6): 782-786. DOI: 10.1192/bjp.150.6.782.

9. Daglar G, Nur N (2018). Level of mother-baby bonding and influencing factors during pregnancy and postpartum period. Psychiatr Danub 30(4): 433-440. DOI: 10.24869/ psyd.2018.433.

10. De Falco S, Emer A, Martini L, Rigo P, Pruner S, Venuti P (2014). Predictors of mother-child interaction quality and child attachment security in at-risk families. Front Psychol 20(5): 898. DOI: 10.3389/fpsyg.2014.00898.

11. Delavari M, Mohammad-Alizadeh-Charandabi S, Mirghafourvand M (2018). The Relationship of MaternalFetal Attachment and Postpartum Depression: A Longitudinal Study. Arch Psychiatr Nurs 32(2): 263-267. DOI: 10.1016/j. apnu.2017.11.013.

12. Dubber S, Reck C, Müller M, Gawlik S (2015). Postpartum bonding: the role of perinatal depression, anxiety and maternalfetal bonding during pregnancy. Arch Womens Ment Health 18(2): 187-195. DOI: 10.1007/s00737-014-0445-4.

13. Eklund A (2016). beeswarm: The Bee Swarm Plot, an Alternative to Stripchart. R package version 0.2.3. [online] [cit. 2020-11-05]. Available from: https://CRAN.R-project.org/ package=beeswarm 
14. Ekrami F, Mohammad-Alizadeh Charandabi S, Babapour Kheiroddin J, Mirghafourvand M (2020). Effect of counseling on maternal-fetal attachment in women with unplanned pregnancy: a randomized controlled trial. J Reprod Infant Psychol 38(2): 151-165.

DOI: 10.1080/02646838.2019.1636943.

15. Falceto OG, Giugliani ER, Fernandes CL (2012). Problematic parent-infant relationships in two-parent families: prevalence and risk factors in a Brazilian neighborhood. Trends Psychiatry Psychother 34(3): 139-146. DOI: 10.1590/S223760892012000300005.

16. Fasanghari M, Kordi M, Asgharipour N (2019). Effect of maternal role training program based on Mercer theory on maternal self-confidence of primiparous women with unplanned pregnancy. J Educ Health Promot 8: 4. DOI: 10.4103/jehp. jehp_202_17.

17. Fuchs A, Möhler E, Reck C, Resch F, Kaess M (2016). The early mother-to-child bond and its unique prospective contribution to child behavior evaluated by mothers and teachers. Psychopathology 49(4): 211-216. DOI: 10.1159/000445439.

18. Hendrych Lorenzová E, Boledovičová M, Kašová L (2016). Péče komunitní porodní asistentky o šestinedělku s poporodní depresí. Pediatr praxi 17(5): 322-325. DOI: 10.36290/ ped.2016.072.

19. Hong YR, Park JS (2012). Impact of attachment, temperament and parenting on human development. Korean J Pediatr 55(12): 449-454. DOI: 10.3345/kjp.2012.55.12.449.

20. Hrubý R (2017). Depresia a včasné emočné, kognitívne a behavirálne regulácie. Martin: VEEM, s.r.o., 275 p.

21. Huizink AC, Menting B, De Moor MHM, Verhage ML, Kunseler FC, Schuengel C, Oosterman M (2017). From prenatal anxiety to parenting stress: a longitudinal study. Arch Womens Ment Health 20(5): 663-672. DOI: 10.1007/s00737-0170746-5.

22. Hyun-Ju C, Sue K (2011). Effects of maternal role practice education on becoming a mother. Korean J Women Health Nurs 17(1): 52-63. DOI: 10.4069/kjwhn.2011.17.1.52.

23. Jamshidimanesh M, Astaraki L, Behboodi Moghadam Z, Taghizadeh Z, Haghani H (2013). Maternal-Fetal Attachment and its Associated Factors. Hayat 18(5): 33-45.

24. Kinsey CB, Baptiste-Roberts K, Zhu J, Kjerulff KH (2014). Birth-related, psychosocial, and emotional correlates of positive maternal-infant bonding in a cohort of first-time mothers. Midwifery 30(5): 188-194. DOI: 10.1016/j.midw.2014.02.006.

25. Kommers DR, Truijens SEM, Oei SG, Bambang Oetomo S, Pop VJM (2017). Antenatal mother-infant bonding scores are related to maternal reports of infant crying behaviour. J Reprod Infant Psychol 35(5): 480-492. DOI: 10.1080/02646838.2017.1354360.

26. Lehnig F, Nagl M, Stepan H, Wagner B, Kersting A (2019). Associations of postpartum mother-infant bonding with maternal childhood maltreatment and postpartum mental health: a cross-sectional study. BMC Pregnancy Childbirth 19(1): 278. DOI: 10.1186/s12884-019-2426-0.

27. Linde K, Lehnig F, Nagl M, Kersting A (2020). The association between breastfeeding and attachment: A systematic review. Midwifery 81: 102592. DOI: 10.1016/j.midw.2019.102592.

28. Lutkiewicz K, Bieleninik Ł, Cieślak M, Bidzan M (2020). Maternal-Infant Bonding and Its Relationships with Maternal Depressive Symptoms, Stress and Anxiety in the Early Postpartum Period in a Polish Sample. Int J Environ Res Public Health 17(15): 5427. DOI: 10.3390/ijerph17155427.

29. Matthies LM, Müller M, Doster A, Sohn C, Wallwiener M, Reck C, Wallwiener S (2020). Maternal-fetal attachment protects against postpartum anxiety: the mediating role of postpartum bonding and partnership satisfaction. Arch Gynecol Obstet 301(1): 107-117. DOI: 10.1007/s00404-019-05402-7.

30. Mazúchová L, Kelčíková S, Porubská A, Malinovská N, Grendár M (2020). Mother-infant bonding in the postpartum period and its predictors. Cent Eur J Nurs Midw 11(3): 121-129. DOI: 10.15452/cejnm.2020.11.0022.

31. McNamara J, Townsend ML, Herbert JS (2019). A systemic review of maternal wellbeing and its relationship with maternal fetal attachment and early postpartum bonding. PLoS One 14(7): e0220032. DOI: 10.1371/journal.pone.0220032.

32. Mohebati LM, Caulfield LE, Martinez H (2014). How much does your baby cry? Expectations, patterns and perceptions of infant crying in Mexico. Bol Med Hosp Infant Mex 71(4): 202-210. DOI: 10.1016/j.bmhimx.2014.08.002.

33. Moore ER, Anderson GC, Bergman N, Dowswell T (2012). Early skin to skin contact for mothers and their healthy newborn infants. Cochrane Database of Systematic Reviews 5(5): CD003519. DOI: 10.1002/14651858.CD003519.pub3

34. Netsi E, Pearson RM, Murray L, Cooper P, Craske MG, Stein A (2018). Association of Persistent and Severe Postnatal Depression with Child Outcomes. JAMA Psychiatry 75(3): 247-253. DOI: 10.1001/jamapsychiatry.2017.4363.

35. Nieto L, Lara MA, Navarrete L (2017). Prenatal Predictors of Maternal Attachment and Their Association with Postpartum Depressive Symptoms in Mexican Women at Risk of Depression. Matern Child Health J 21(6): 1250-1259. DOI: 10.1007/ s10995-016-2223-6.

36. Nóblega M, Bárrig P, Fourment K (2019). Maternal Care and Attachment Security in Preschool Children. Psic Teor e Pesq 35: e3534. DOI: 10.1590/0102.3772e3534.

37. Örün E, Yalçın SS, Mutlu B (2013). Relations of maternal psychopathologies, social-obstetrical factors and mother-infant bonding at 2-month postpartum: a sample of Turkish mothers. World J Pediatr 9(4): 350-355. DOI: 10.1007/s12519-0130432-2.

38. Pereira PK, Lima LA, Legay LF, de Cintra Santos JF, Lovisi GM (2012). Maternal mental disorders in pregnancy and the puerperium and risks to infant health. World J Clin Pediatr 1(4): 20-23. DOI: 10.5409/wjcp.v1.i4.20.

39. Petri E, Palagini L, Bacci O, Borri C, Teristi V, Corezzi C, et al. (2018). Maternal-foetal attachment independently predicts the quality of maternal-infant bonding and post-partum psychopathology. J Matern Fetal Neonatal Med 31(23): 3153-3159. DOI: 10.1080/14767058.2017.1365130.

40. Phillips, R (2013). The Sacred Hour: Uninterrupted Skin-to-Skin Contact Immediately After Birth. Newborn Infant Nurs Rev 13(2): 67-72. DOI: 10.1053/j.nainr.2013.04.001.

41. R Core Team (2018). R: A language and environment for statistical computing. R Foundation for Statistical Computing, Vienna, Austria. [online] [cit. 2020-11-05]. Available from: https://www.R-project.org/

42. Salehi K, Kohan S (2017). Maternal-fetal attachment: what we know and what we need to know. Int J Pregn Chi Birth 2(5): 146-148. DOI: 10.15406/ipcb.2017.02.00038.

43. Sjoberg DD, Curry M, Hannum M, Whiting K, Zabor EC, Drill E, et al. (2020). gtsummary: Presentation-Ready Data Summary and Analytic Result Tables. R package version 1.3.3. [online] [cit. 2020-11-05]. Available from: https://CRAN.R-project.org/ package $=$ gtsummary

44. Zeifman DM, St James-Roberts I (2017). Parenting the Crying Infant. Curr Opin Psychol 15: 149-154. DOI: 10.1016/j. copsyc.2017.02.009. 